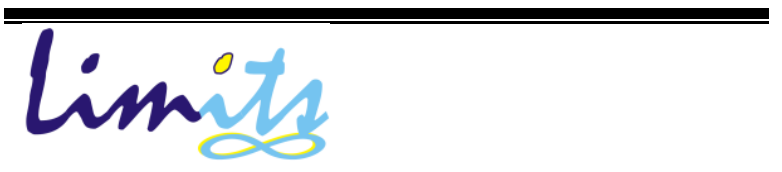

Limits: Journal of Mathematics and Its Applications

E-ISSN: 2579-8936

P-ISSN: $1829-605 \mathrm{X}$

Vol. 16, No. 2, Desember 2019, 95-104

DOI: http://dx.doi.org/10.12962/limits.v16i2.6043

\title{
Uji Resolusi Tomografi Seismik Waktu Tempuh Lokal Menggunakan Dua Input Model Sintetik
}

\author{
Mohamad Ramdhan ${ }^{1 *}$, Said Kristyawan ${ }^{2}$, Andry Syaly Sembiring ${ }^{3}$, Daryono ${ }^{4}$ Priyobudi $^{5}$ \\ 1,2,3,4,5 Badan Meteorologi, Klimatologi, dan Geofisika (BMKG); Jl. Angkasa I No.2 Kemayoran, \\ Jakarta Pusat, 10720 \\ *e-mail: mohamad.ramdhan@bmkg.go.id/ mramdhan123@gmail.com
}

\begin{abstract}
Abstrak
Uji resolusi dalam tomografi seismik telah diterapkan secara luas pada berbagai skala. Uji tersebut digunakan untuk mengetahui kehandalan data seismik yang digunakan pada suatu area penelitian. Checkerboard resolution test (CRT) merupakan salah satu teknik uji resolusi yang diterapkan secara luas pada data tomografi seismik. Uji resolusi dilakukan untuk mengetahui secara spasial area mana saja yang bisa diinterpretasi dari suatu tomogram seismik. Pada penelitian ini akan menguji resolusi dengan input model CRT dan Non-CRT. Area yang memiliki kemiripan pola antara input model dan hasil inversinya menunjukkan area tersebut bisa diinterpretasi baik secara geologi maupun dari properti fisika batuannya. Pada uji resolusi model Non-CRT juga ditambahkan random noise untuk mengetahui sejauh mana pengaruh noise terhadap data seismik. Hasil uji resolusi pada kedua input model tersebut menunjukan konsistensi pada area-area yang bisa diinterpretasi ataupun tidak. Hal ini menunjukkan data seismik yang digunakan pada penelitian ini memiliki kualitas yang cukup baik sehingga hasil studi tomografinya bisa menjelaskan kondisi geologi di bawah permukaannya.
\end{abstract}

Kata Kunci: resolusi; seismik; tomografi; interpretasi.

\begin{abstract}
Resolution tests in seismic tomography have been widely implemented at various scales. The tests are used to determine the reliability of seismic data used in a study area. A checkerboard resolution test (CRT) is one of the resolution test techniques that is widely applied in seismic tomography data. The resolution test is carried out on seismic tomography data to determine spatially which areas can be interpreted from a tomogram. In this study, we test a number of resolution tests with CRT and Non-CRT input models. Areas that have similar patterns between input models and inversion results indicate that the area can be interpreted both geologically and from the properties of rock physics. In this resolution test also added random noise to determine the effect of noise on seismic data at the Non-CRT model. The resolution test results of two models show consistency in areas that can be interpreted or not. These show that the seismic data used in this study has good quality so that the results of the tomographic study can explain the subsurface geological condition.
\end{abstract}

Keywords: resolution; tomography; sesmic; interpretation.

\section{Pendahuluan}

Tomografi seismik waktu tempuh merupakan salah satu metode geofisika yang sangat powerfull untuk mencitrakan interior dalam bumi baik pada skala lokal, regional dan global. Tomografi seismik global telah berhasil diaplikasikan untuk memahami proses evolusi bumi yang 
terjadi selama puluhan juta tahun. Evolusi Busur Sunda selama puluhan juta tahun dapat dijelaskan dengan baik dari citra tomografi tersebut [1]. Studi tomografi seismik lokal berhasil menjelaskan hubungan antara zona subduksi dan busur vulakanik sebagaimana telah diaplikasikan di Jawa Tengah dan sekitarnya [2], [3]. Penggunaan tomografi seismik skala lokal juga dapat digunakan untuk mengetahui karakteristik reservoir magma gunung api dan sistem panas bumi yang berhasil diaplikasikan di sejumlah area di Indonesia. Sistem magma gunung api yang berhasil dijelaskan karakteristiknya dengan studi tomografi seismik waktu tempuh lokal diantaranya: sistem magma di bawah Gunung Guntur, Gunung Sinabung dan Gunung Merapi [4]-[7]. Sistem reservoir panas bumi juga berhasil dijelaskan dengan baik oleh studi tomografi seismik waktu tempuh sebagaimana diaplikasikan di area sistem panas bumi Tarutung Sumatera Utara [8].

Kondisi geologi dan properti fisika batuan di bawah permukaan suatu area dapat dipahami dari suatu tomogram jika memiliki kualitas data yang baik. Kualitas data yang baik bisa dilihat dari uji resolusi data seismik tersebut. Jika suatu data seismik berhasil melewati uji resolusi maka data tersebut bisa digunakan untuk mengetahui kondisi bawah permukaannya. Studi ini menampilkan uji resolusi seismik dengan dua input model sintetik yang berbeda. Uji resosusi pada data tomografi seismik mengunakan beberapa teknik. Teknik yang paling klasik digunakan untuk uji resolusi adalah menggunakan Checkerboard Resolution Test (CRT) [9]. Selain teknik CRT, studi ini juga akan menggunakan input model yang berbeda dengan CRT.

\section{Data dan Metodologi}

Data yang digunakan untuk studi ini menggunakan data sintetik yang berasal dari gempagempa yang direkam oleh jaringan seismik DOMERAPI dan BMKG dengan periode perekaman dari Bulan Oktober 2013 sampai pertengan Bulan April 2015. Proyek DOMERAPI dilaksanakan untuk mengetahui sistem reservoir utama di bawah Gunung Merapi [6], [7]. Jumlah gempa yang digunakan pada studi ini sebanyak 358 dengan masing-masing fase gelombang $\mathrm{P}$ dan $\mathrm{S}$ sejumlah 5042 sebagaimana telah digunakan pada studi sebelumnya [7]. Data gempa yang direkam merupakan jenis gempa lokal karena jarak dari sumber gempa ke stasiun seismik pencatatnya kurang dari $1000 \mathrm{~km}$ [10]. Jarak maksimum dari sumber gempa ke stasiun seismik pada studi ini kurang dari $500 \mathrm{~km}$. Data-data gempa tersebut berhasil digunakan untuk mendeteksi sistem magma di bawah Gunung Merapi yang terdiri dari reservoir magma dangkal, menengah dan dalam yang dicirikan dengan tingginya nilai rasio Vp/Vs [7]. Data-data gempa tersebut digunakan untuk mendapatkan waktu tempuh dari model sintetik CRT dan Non-CRT yang digunakan untuk uji resolusi data seismik pada penelitian ini. Waktu tempuh tersebut didapatkan dengan teknik 
forward modelling (pemodelan kedepan). Sumber-sumber gempa yang direkam oleh jaringan seismik melewati medium pada model kecepatan CRT dan Non-CRT (gambar 1(b), 2(a) dan 2(c)). Waktu tempuh sintetik dari kedua model tersebut digunakan sebagai waktu tempuh observasi pada setiap stasiun seismik yang merekam gempa. Waktu tempuh tersebut diinversi untuk mendapatkan model kecepatan final (Kecepatan gelombang $\mathrm{P}(\mathrm{Vp})$ dan rasio $\mathrm{Vp} / \mathrm{Vs}$ ). Selain dari data waktu tempuh observasi inversi juga memerlukan model kecepatan awal yang akan diiterasi sampai proses inversi selesai menjadi model kecepatan final. Inversi yang digunakan menggunakan inversi nonlinier dengan pendekatan linier. Model $\mathrm{Vp}$ dan rasio $\mathrm{Vp} / \mathrm{Vs}$ pada suatu area harus memiliki pola yang mirip dengan input model awal (CRT dan Non-CRT) sehingga area tersebut bisa diinterpretasi. Nilai model kecepatan dan rasio $\mathrm{Vp} / \mathrm{Vs}$ antara model input dan hasil inversi nilainya tidak akan pernah sama. Nilai kecepatan hasil inversi sebesar 30-50 persen dari input model awal sudah cukup menunjukkan suatu area teresolusi dengan baik [6].

Forward modelling dan inversi seismik yang digunakan pada studi ini menggunakan code SIMULPS12 [11]-[13]. Metode ray tracing (penjejakan sinar gelombang seismik) yang digunakan pada program tersebut menggunakan metode pseudo bending [14]. Metode tersebut menggunakan Prinsip Fermat, dimana jika gelombang merambat dari satu titik ke titik lain maka gelombang tersebut akan melewati lintasan dengan waktu tercepat. Penjejakan sinar sangat berguna untuk menghitung waktu tempuh kalkulasi dari sumber gempa menuju stasiun penerima berdasarkan model referensi bumi. Inversi yang digunakan adalah inversi $\mathrm{Vp}$, rasio $\mathrm{Vp} / \mathrm{Vs}$ dan hiposenter secara simultan. Adapun nilai Vs didapatkan dari hasil pembagian Vp dengan rasio Vp/Vs. Model kecepatan awal yang digunakan pada studi ini menggunakan model Vp 1-D pada area Jawa Tengah dan sekitarnya [2] dengan rasio Vp/Vs sebesar 1,73 yang merupakan Wadati Diagram dari data gempa yang direkam oleh jaringan seismik DOMERAPI dan BMKG [15], [16].

\section{Hasil dan Pembahasan}

\subsection{Model Sintetik CRT}

Model input pada studi ini menggunakan nilai kecepatan $\pm 10 \%$ terhadap model kecepatan awal $\mathrm{Vp}$ dan rasio $\mathrm{Vp} / \mathrm{Vs}$ yang digunakan untuk input inversi tomografi seismik. Model input awal digunakan untuk mendapatkan waktu tempuh gelombang seismik sintetik yang didapat dengan teknik forward modelling sebagaimana dijelaskan pada sub bahasan sebelumnya. Waktu tempuh tersebut kemudian diinversi kembali untuk mendapatkan nilai $\mathrm{Vp}$ dan rasio Vp/Vs. Gambar 1 menunjukkan area penelitian, input model sintetik CRT dan hasil inversinya. 
Parameterisasi model merupakan hal yang harus dilakukan pertama kali untuk perhitungan tomografi seismik [17]. Dua hal paling penting dalam parameterisasi model adalah penentuan ukuran grid dan model kecepatan awal yang digunakan. Target area studi, distribusi stasiun dan distribusi event gempa menjadi faktor pertimbangan utama untuk menentukan ukuran grid. Pada daerah dengan kerapatan stasiun dan event gempa yang tinggi digunakan ukuran grid yang relatif kecil. Model awal kecepatan yang digunakan sebisa mungkin harus mendekati model sebenarnya agar solusi yang digunakan berada pada daerah minimum global [18]. Penggunaan hasil studi terdahulu dan pendekatan dari data geologi dapat digunakan untuk penentuan model kecepatan awal. Selain itu, model kecepatan awal yang tepat juga sangat berguna dalam mempersingkat waktu komputasi karena proses iterasinya akan lebih sedikit.

Ukuran grid vertikal dan horisontal yang digunakan sama dengan studi terdahulu [7]. Ukuran grid yang digunakan tidak seragam tetapi disesuaikan dengan kriteria sebagaimana dijelaskan di atas. Grid vertikal menggunakan ukuran minimal sebesar $5 \mathrm{~km}$ dan untuk grid horisontal sebesar $10 \mathrm{~km}$. Sistem reservoir magma yang berada pada kedalaman $5 \mathrm{~km}, 15 \mathrm{~km}$ dan lebih dari $20 \mathrm{~km}$ merupakan target studi dari proyek DOMERAPI sehingga ukuran grid vertikal yang digunakan sebesar $5 \mathrm{~km}$ dari kedalaman 0-30 km. Untuk kedalaman yang lebih dalam dari $30 \mathrm{~km}$ menggunakan ukuran grid yang lebih besar. Ukuran grid yang tidak seragam juga berhasil diaplikasikan dengan baik untuk studi tomografi seismik lokal di bawah Sesar San Andreas, Amerika Serikat [19]. Sebaran data gempa dan ukuran grid yang digunakan pada penelitian ini dapat dilihat pada publikasi sebelumnya [6], [7]. 
a)

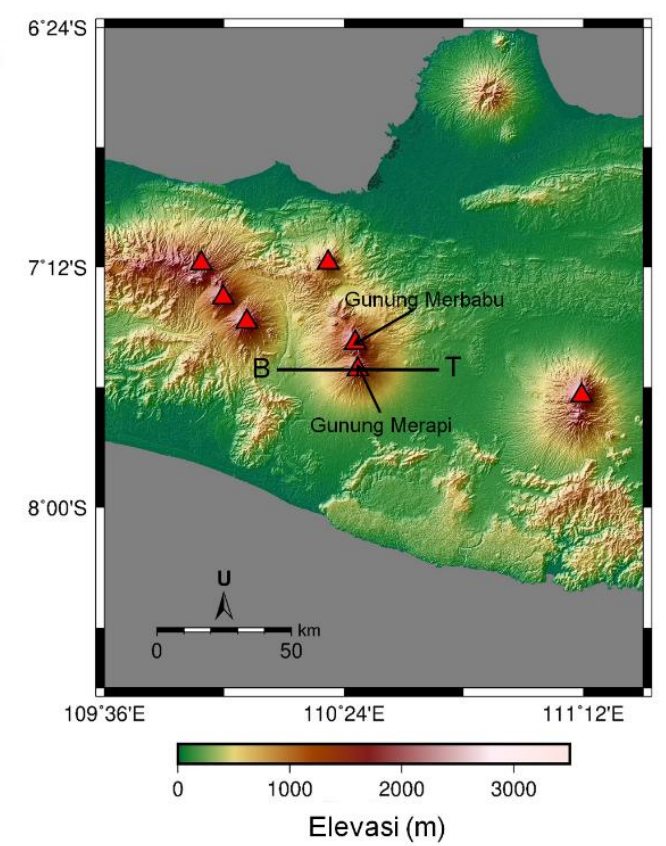

C)

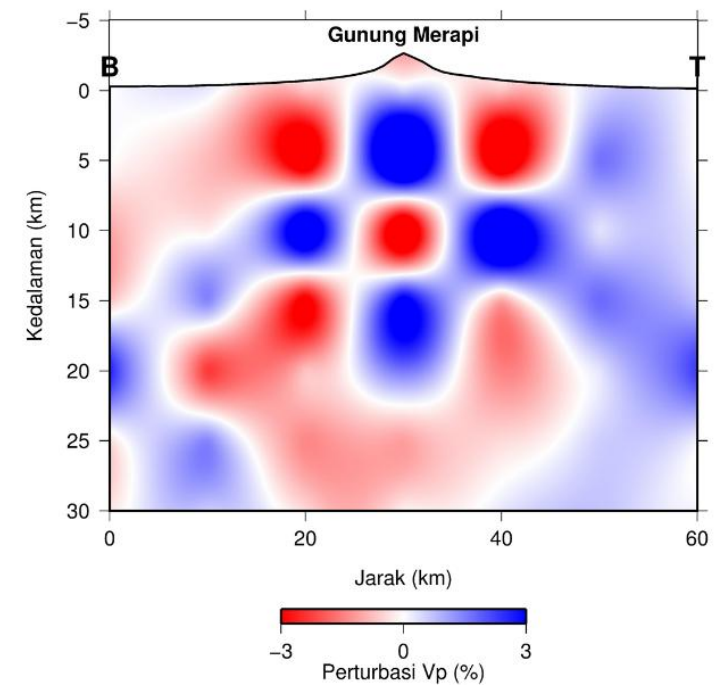

b)

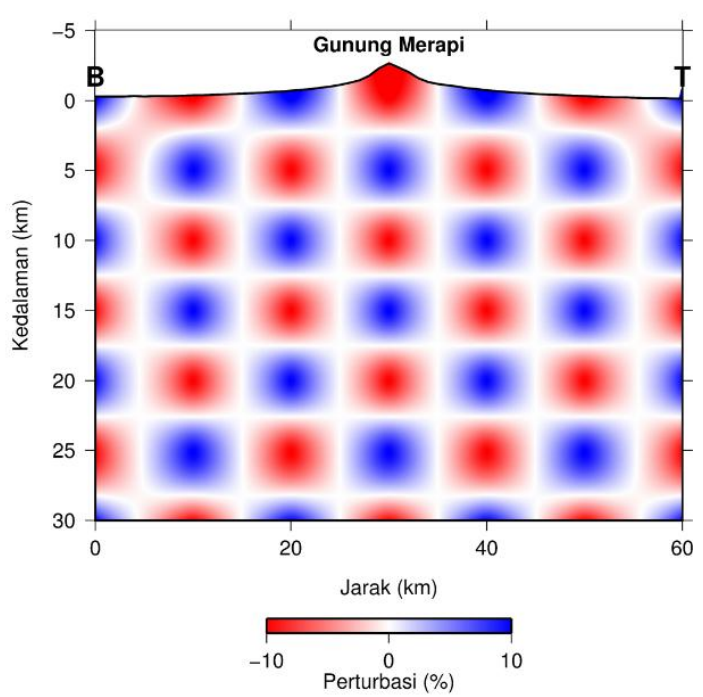

d)

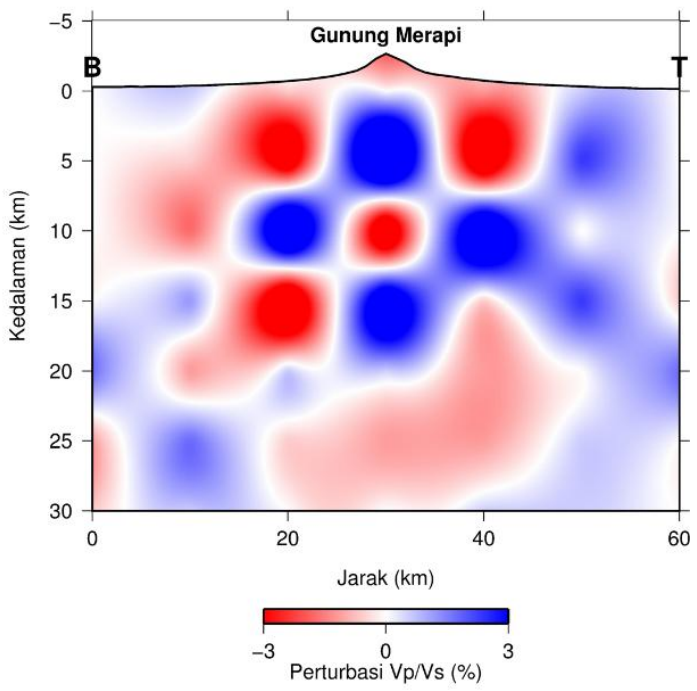

Gambar 1 a) Garis penampang arah barat-timur (B-T) yang melewati Gunung Merapi. b) Input model sintetik CRT $\pm 10 \%$ terhadap model awal Vp dan rasio $\mathrm{Vp} / \mathrm{Vs}$. Model kecepatan awal berasal dari model kecepatan di area Jawa tengah dan sekitarnya [2]. Adapun untuk model awal rasio $\mathrm{Vp} / \mathrm{Vs}$ berasal dari Diagram Wadati yang berasal dari katalog gempa yang direkam oleh jaringan seismik DOMERAPI dan BMKG [15]. c) Hasil tes CRT untuk Vp. d) Sama dengan (c) tetapi untuk rasio $\mathrm{Vp} / \mathrm{Vs}$.

Hasil tes CRT menunjukkan bahwa tomogram Vp dan rasio Vp/Vs pada jarak 20-40 km dengan kedalaman 0-20 km bisa recovery dengan baik. Adapun di luar area tersebut berlaku sebaliknya. Sejumlah artefak juga terdapat pada jarak $10 \mathrm{~km}$ dan $50 \mathrm{~km}$ dengan rentang kedalaman dari 0-20 km. Artefak-artefak tersebut pada sampling data yang tidak terlalu baik tidak bisa diabaikan begitu saja sehingga artefak-artefak tersebut mewakili area yang bisa diinterpretasi [20]. 
Hasil tes CRT menunjukkan bahwa area yang bisa diinterpretasi secara geologi berada pada jarak 10-50 km dengan kedalaman dari 0-20 km.

\subsection{Model Sintetik Non-CRT}

Model sintetik non-CRT yang digunakan pada studi ini ditunjukkan pada Gambar 2(a) untuk Vp dan 2(c) untuk rasio Vp/Vs. Model anomali negatif digunakan sebagai input model Vp dan model anomali positif untuk input model rasio Vp/Vs. Kedua anomali tersebut umum dijumpai pada sejumlah gunung api aktif yang ada di dunia [2], [4], [6], [7], [21]. Anomali Vp yang rendah dengan rasio $\mathrm{Vp} / \mathrm{Vs}$ yang tinggi berkaitan dengan magma yang memiliki kandungan material molten dan fluida. Anomali $\mathrm{Vp}$ rendah dan rasio $\mathrm{Vp} / \mathrm{Vs}$ yang tinggi juga disebabkan oleh porositas batuan yang cukup tinggi di bawah gunung api aktif. Hasil inversi menunjukkan baik Vp dan rasio $\mathrm{Vp} / \mathrm{Vs}$ dapat recovery dengan cukup baik. Area pada kedalaman 0-20 km dapat kembali dengan cukup baik sehingga data tomografi seismik sebenarnya pada area tersebut dapat diinterpretasi. 
a)

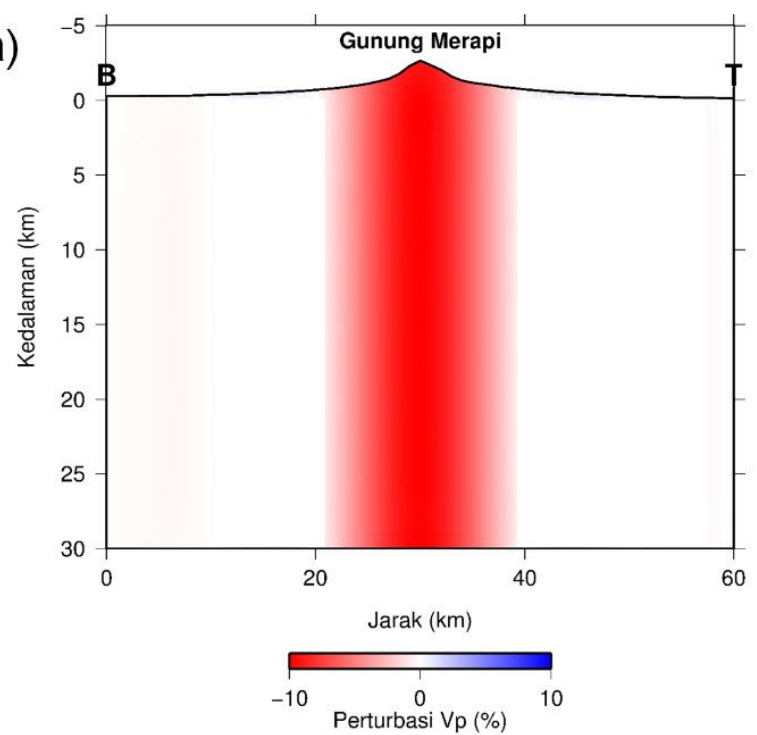

c)

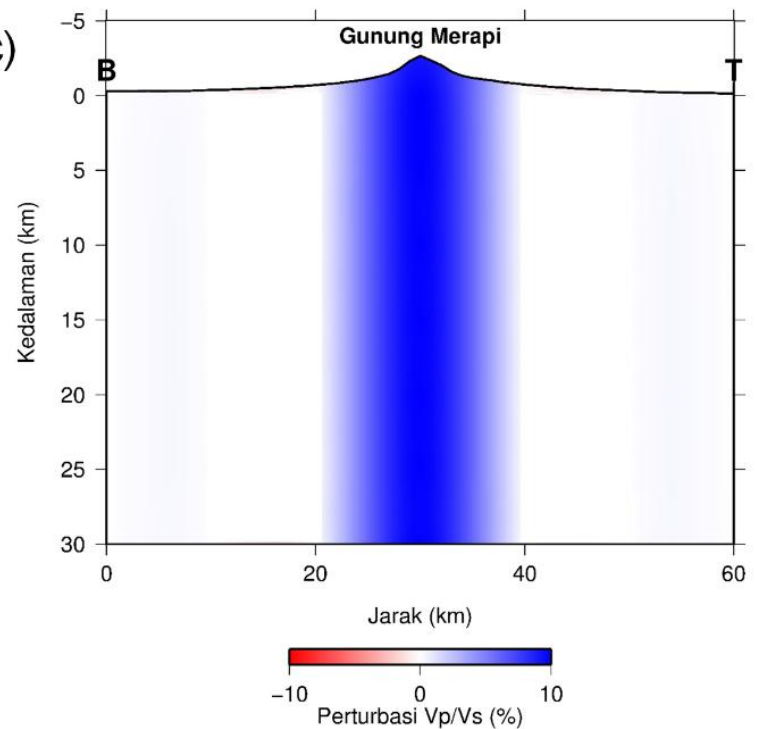

b)

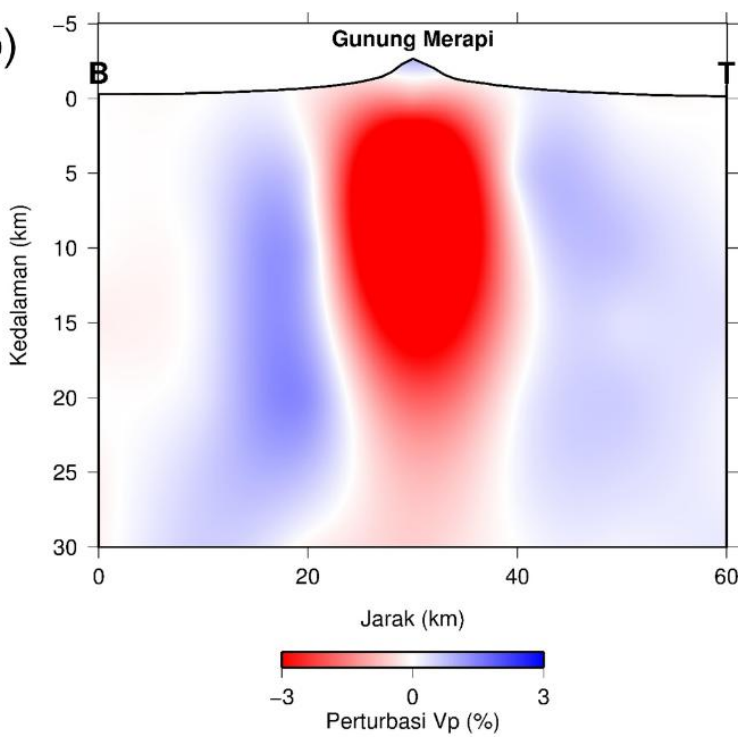

d)

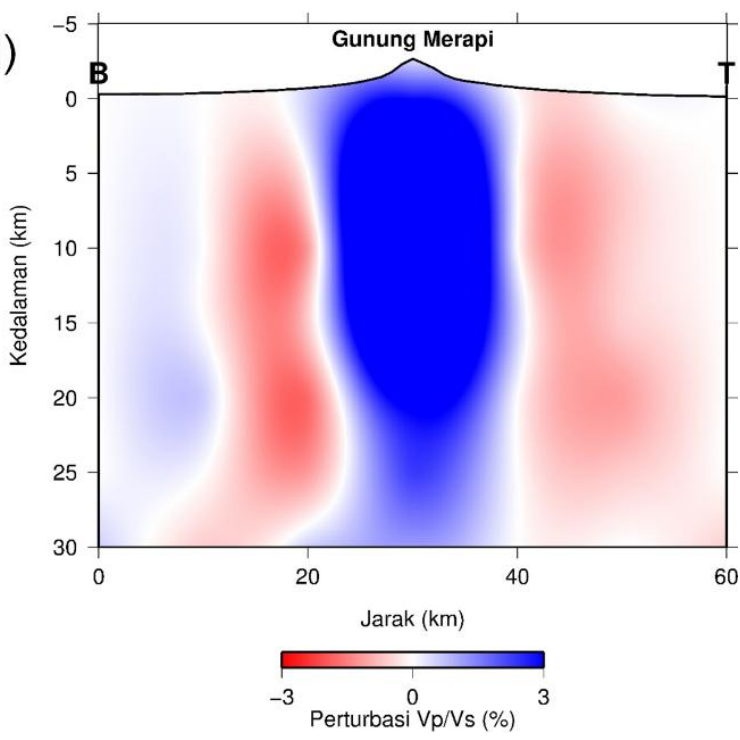

Gambar 2 a) Input model sintetik -10\% terhadap model awal Vp pada arah barat-timur yang melewati Gunung Merapi. b) Hasil inversi dari input model Vp. c) Input model sintetik $+10 \%$ terhadap model awal rasio $\mathrm{Vp} / \mathrm{Vs}$ pada arah barat-timur yang melewati Gunung Merapi. d) Hasil inversi dari input model rasio $\mathrm{Vp} / \mathrm{Vs}$

Data seismik yang diproses tidak akan pernah terlepas dari noise. Noise bisa kita minimalisasi dengan berbagi cara tetapi tidak akan pernah habis seluruhnya. Noise tidak akan menjadi masalah selama nilai Signal to noise Ratio (SNR) tinggi. Noise juga bisa diakibatkan oleh adanya nilai ketidakpastian ketika picking waktu tiba gelombang $\mathrm{P}$ dan $\mathrm{S}$ pada seismogram. Penambahan random noise bisa dilakukan pada data waktu tempuh hasil forward modeling. Penambahan noise tersebut bertujuan untuk mengetahui sejauh mana pengaruh noise terhadap data seismik yang digunakan. Gambar 3 menunjukkan distribusi random noise Gaussian yang ditambahkan pada data sintetik model satu kolom. Hasil inversi yang 
ditunjukkan oleh Gambar 4 memperlihatkan bahwa area di bawah Gunung Merapi sebagai target penelitian masih bisa recovery dengan baik sehingga area tersebut masih bisa diinterpretasi. Penambahan noise dalam suatu data seismik akan menyebabkan nilai perturbasi dari hasil inversi semakin tinggi sebagaimana diperlihatkan pada Gambar 4. Hasil ini menunjukkan semakin tinggi noise akan semakin menghilangkan data seismik sehingga meminimalkan noise adalah hal mutlak yang harus dilakukan dalam pengolahan data seismik.

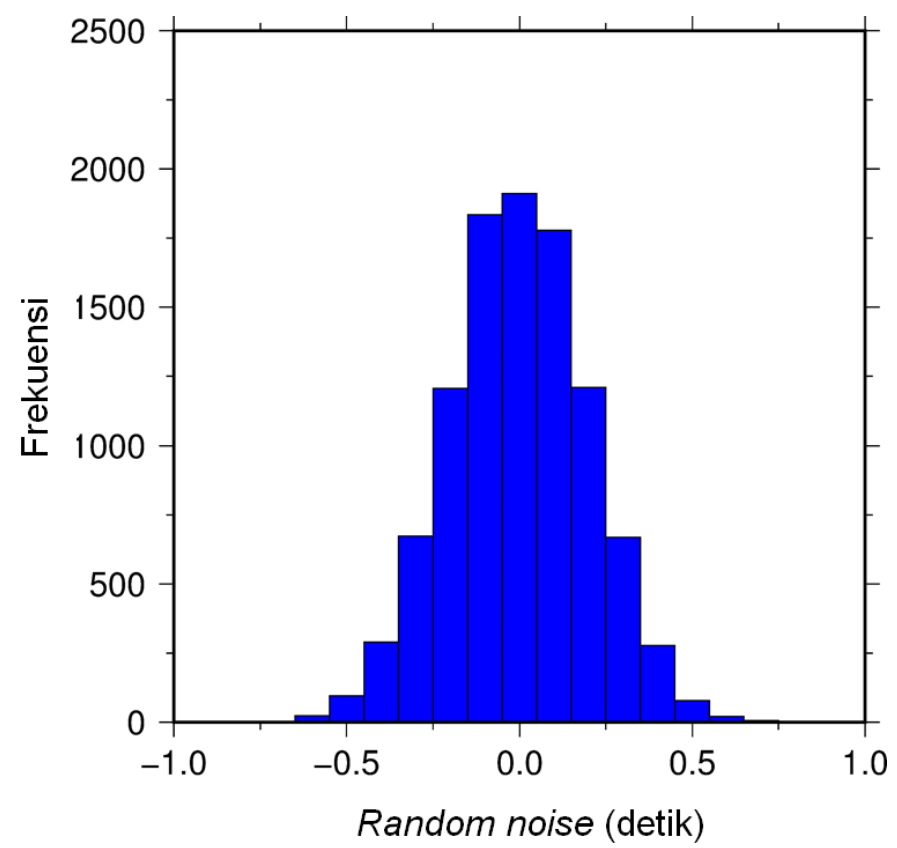

Gambar 3 Data Gaussian random noise yang ditambahkan pada waktu tempuh hasil forward modelling yang dihasilkan pada model input gambar 2(a) dan 2(c). Nilai standar deviasi yang digunakan sebesar 0,2 .

a)

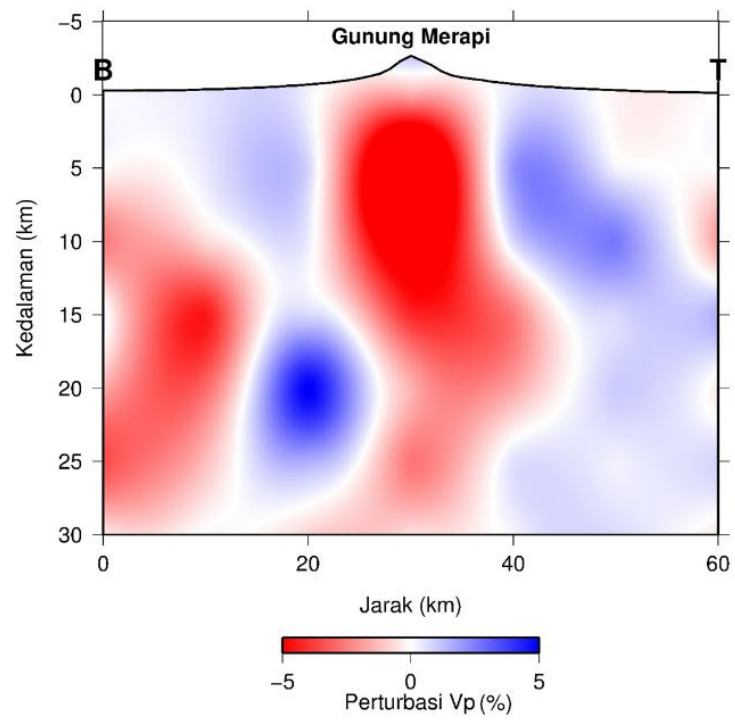

b)

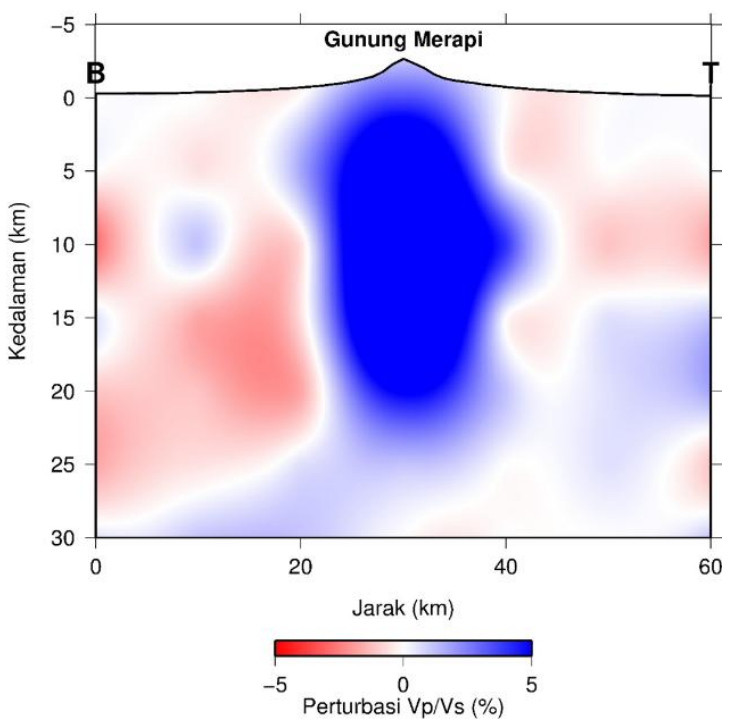

Gambar 4 a) Hasil inversi untuk Vp setelah ditambahkan random noise. b) Sama dengan (a) tetapi untuk rasio $\mathrm{Vp} / \mathrm{Vs}$. 


\section{Simpulan}

Uji resolusi yang dilakukan pada studi ini menunjukkan inversi pada data seismik sebenarnya dapat bekerja dengan baik yang ditunjukkan dengan konsistensi area yang bisa dinterpretasi ataupun tidak pada kedua input model yang digunakan. Area yang bisa dïnterpretasi di bawah Gunung Merapi dari jaringan seismik yang digunakan pada studi ini berada pada kedalaman antara $0-20 \mathrm{~km}$. Uji resolusi juga memberikan pengetahuan tentang batasan data seismik yang digunakan sehingga kita bisa mengetahui resolusi minimal untuk mendeteksi struktur bawah permukaan. Pengaruh noise dalam suatu data seismik juga berhasil ditunjukkan pada studi ini dimana kualitas tomogram seismik terdegradasi dengan kehadiran noise.

\section{Ucapan Terima Kasih}

Kami ucapkan rasa terima kasih kepada pihak-pihak yang terlibat pada penelitian ini terutama Institut de Recherche pour le Dèveloppement (IRD), Prancis yang telah membiayai proyek DOMERAPI dan Badan Meteorologi, Klimatologi, dan Geofisika (BMKG) yang telah memberikan akses data waveform gempa sehingga penelitian ini berjalan dengan lancar. Kami juga mengucapkan terima kasih kepada Pusat Vulkanologi dan Mitigasi Bencana Geologi (PVMBG) sebagai mitra utama Proyek DOMERAPI di Indonesia. Semua gambar pada tulisan ini diplot menggunakan program Generic Mapping Tools [22].

\section{Daftar Pustaka}

[1] S. Widiyantoro dan R. van der Hilst, "Structure and Evolution of Lithospheric Slab Beneath the Sunda Arc, Indonesia," Science, vol. 271, no. 5255, pp. 1566-1570, Mar. 1996.

[2] I. Koulakov dkk., "P and S velocity structure of the crust and the upper mantle beneath central Java from local tomography inversion," Journal of Geophysical Research: Solid Earth, vol. 112, no. B8, 2007.

[3] S. Rohadi, S. Widiyantoro, A. Nugraha, dan Masturyono, "Tomographic imaging of Pand S-wave velocity structure beneath Central Java, Indonesia: Joint inversion of the MERAMEX and MCGA earthquake data," International Journal of Tomography \& Simulation $^{T M}$, vol. 24, no. 3, pp. 1-16, 2013.

[4] A. D. Nugraha, S. Widiyantoro, A. Gunawan, dan G. Suantika, "Seismic Velocity Structures beneath the Guntur Volcano Complex, West Java, Derived from Simultaneo us Tomographic Inversion and Hypocenter Relocation," Journal of Mathematical and Fundamental Sciences, vol. 45, no. 1, pp. 17-28, 2013.

[5] A. D. Nugraha dkk., "Joint 3-D tomographic imaging of $\mathrm{Vp}, \mathrm{Vs}$ and $\mathrm{Vp} / \mathrm{Vs}$ and hypocenter relocation at Sinabung volcano, Indonesia from November to December 2013," Journal of Volcanology and Geothermal Research, Sep. 2017. 
[6] M. Ramdhan dkk., "Detailed seismic imaging of Merapi volcano, Indonesia, from local earthquake travel-time tomography," Journal of Asian Earth Sciences, vol. 177, pp. 134145, Jun. 2019.

[7] S. Widiyantoro dkk., "Seismic imaging and petrology explain highly explosive eruptions of Merapi Volcano, Indonesia," Scientific Reports, vol. 8, no. 1, p. 13656, Sep. 2018.

[8] U. Muksin, K. Bauer, dan C. Haberland, "Seismic Vp and Vp/Vs structure of the geothermal area around Tarutung (North Sumatra, Indonesia) derived from local earthquake tomography," Journal of Volcanology and Geothermal Research, vol. 260, pp. 27-42, 2013.

[9] J.-J. Lévěque, L. Rivera, dan G. Wittlinger, "On the use of the checker-board test to assess the resolution of tomographic inversions," Geophysical Journal International, vol. 115, no. 1, pp. 313-318, 1993.

[10] J. Havskov dan L. Ottemöller, "Introduction," in Routine Data Processing in Earthquake Seismology, Springer, 2010, pp. 9-10.

[11] D. Eberhart-Phillips, "Local earthquake tomography: earthquake source regions," Seismic Tomography: Theory and Practice, pp. 613-643, 1993.

[12] J. R. Evans, D. Eberhart-Phillips, dan C. Thurber, 'User's manual for SIMULPS12 for imaging $\mathrm{Vp}$ and $\mathrm{Vp} / \mathrm{Vs}$; a derivative of the" Thurber" tomographic inversion SIMUL3 for local earthquakes and explosions," US Geological Survey, 1994.

[13] C. Thurber, Local earthquake tomography: velocities and $V p / V s$-theory in Seismic Tomography: Theory and Practice pp. 563-583 eds Iyer HM, Hirahara K. Chapman \& Hall London, 1993.

[14] J. Um dan C. Thurber, "A fast algorithm for two-point seismic ray tracing," Bulletin of the Seismological Society of America, vol. 77, no. 3, pp. 972-986, 1987.

[15] M. Ramdhan dkk., "Relocation of hypocenters from DOMERAPI and BMKG networks: a preliminary result from DOMERAPI project," Earthquake Science, May 2017.

[16] K. Wadati, "On the travel time of earthquake waves II," Geophys. Mag, vol. 7, pp. 101$111,1933$.

[17] E. Kissling, S. Husen, dan F. Haslinger, "Model parametrization in seismic tomography: a choice of consequence for the solution quality," Physics of the Earth and Planetary Interiors, vol. 123, no. 2, pp. 89-101, Apr. 2001.

[18] H. Grandis, "Pengantar pemodelan inversi geofisika," Bandung: Himpunan Ahli Geofisika Indonesia, 2009.

[19] C. Thurber dan D. Eberhart-Phillips, "Local earthquake tomography with flexible gridding," Computers \& Geosciences, vol. 25, no. 7, pp. 809-818, 1999.

[20] E. Kissling, "Geotomography with local earthquake data," Reviews of Geophysics, vol. 26, no. 4, pp. 659-698, 1988.

[21] J. Nakajima, T. Matsuzawa, A. Hasegawa, dan D. Zhao, "Three-dimensional structure of $\mathrm{Vp}, \mathrm{Vs}$, and $\mathrm{Vp} / \mathrm{Vs}$ beneath northeastern Japan: Implications for arc magmatism and fluids," Journal of Geophysical Research: Solid Earth, vol. 106, no. B10, pp. 2184321857, 2001.

[22] P. Wessel dan W. H. Smith, "New improved version of Generic Mapping Tools released," Eos, Transactions American Geophysical Union, vol. 79, no. 47, pp. 579, 1998. 